\title{
Article \\ Beneficial Effects of Silicon Fertilizer on Growth and Physiological Responses in Oil Palm
}

\author{
Saowapa Duangpan ${ }^{1,2, *}$, Yanipha Tongchu ${ }^{1}$, Tajamul Hussain ${ }^{1}$, Theera Eksomtramage ${ }^{2,3}$ and Jumpen Onthong ${ }^{3}$ \\ 1 Laboratory of Plant Breeding and Climate Resilient Agriculture, Agricultural Innovation and Management \\ Division, Faculty of Natural Resources, Prince of Songkla University, Hat Yai, Songkhla 90110, Thailand; \\ 6010620055@psu.ac.th (Y.T.); $6110630006 @ p s u . a c . t h$ (T.H.) \\ 2 Oil Palm Agronomical Research Center, Faculty of Natural Resources, Prince of Songkla University, \\ Hat Yai, Songkhla 90110, Thailand; theera.e@psu.ac.th \\ 3 Agricultural Innovation and Management Division, Faculty of Natural Resources, Prince of Songkla \\ University, Hat Yai, Songkhla 90110, Thailand; jumpen.o@psu.ac.th \\ * Correspondence: saowapa.d@psu.ac.th; Tel.: +66-74-286-138
}

Citation: Duangpan, S.; Tongchu, Y.; Hussain, T.; Eksomtramage, T.; Onthong, J. Beneficial Effects of Silicon Fertilizer on Growth and Physiological Responses in Oil Palm. Agronomy 2022, 12, 413. https:// doi.org/10.3390/agronomy12020413

Academic Editors: Christos Noulas, Shahram Torabian and Ruijun Qin

Received: 31 December 2021

Accepted: 4 February 2022

Published: 7 February 2022

Publisher's Note: MDPI stays neutral with regard to jurisdictional claims in published maps and institutional affiliations.

Copyright: (C) 2022 by the authors. Licensee MDPI, Basel, Switzerland. This article is an open access article distributed under the terms and conditions of the Creative Commons Attribution (CC BY) license (https:// creativecommons.org/licenses/by/ $4.0 /)$.

\begin{abstract}
Vigorous and well-established nursery seedlings are an important component of sustainable oil palm production. We postulated that $\mathrm{Si}$ fertilization at the seedling stage could help to achieve improved performance of oil palm seedlings leading to healthy and vigorous nursery establishment. In this study, we evaluated the growth and physiological responses of oil palm Tenera hybrid seedlings under three $\mathrm{Si}$ fertilization treatments and a control including (i) $0 \mathrm{~g} \mathrm{Ca}_{2} \mathrm{SiO}_{4}$ (T0), (ii) $0.5 \mathrm{~g} \mathrm{Ca}_{2} \mathrm{SiO}_{4}$ (T1), (iii) $3.5 \mathrm{~g} \mathrm{Ca}_{2} \mathrm{SiO}_{4}$ (T2), and (iv) $7.0 \mathrm{~g} \mathrm{Ca}_{2} \mathrm{SiO}_{4}$ (T3) per plant per month. $\mathrm{Ca}_{2} \mathrm{SiO}_{4}$ was used as the Si fertilizer source and was applied for four consecutive months. Nondestructive data including stem diameter, plant height, leaf length, photosynthetic rate, leaf angle, and leaf thickness and destructive data including leaf, stem, and root fresh weight and dry weight, as well as chlorophyll $a$, Si, and nitrogen contents, were recorded before treatment (0 DAT), as well as 60 (60 DAT) and 120 days after treatment (120 DAT). Results indicated that Si fertilization enhanced Si accumulation in oil palm seedlings, and maximum accumulation was observed in the aerial parts especially the leaves with the highest accumulation of $0.89 \%$ dry weight at T3. Higher Si accumulation stimulated the growth of seedlings; a total fresh weight of $834.28 \mathrm{~g}$ and a total dry weight of $194.34 \mathrm{~g}$ were observed at T3. Chlorophyll $a$ content $\left(0.83 \mathrm{gm}^{-2}\right)$ and net photosynthetic rate $\left(4.98 \mu \mathrm{M} \mathrm{CO}_{2} \cdot \mathrm{m}^{-2} \cdot \mathrm{s}^{-1}\right)$ were also observed at T3. Leaf morphology was not significantly influenced under Si fertilization, whereas the nitrogen content of seedlings was significantly increased. Correlation analysis revealed a highly significant and positive association among $\mathrm{Si}$ accumulation, chlorophyll $a$ content, photosynthetic rate, total fresh weight, total dry weight, and nitrogen content of seedlings, indicating that Si fertilization enhanced the performance of these attributes. On the basis of the research evidence, it was concluded that $\mathrm{Si}$ fertilization should be considered for improved nutrient management for oil palm seedling and nursery production.
\end{abstract}

Keywords: silicon fertilization; oil palm; growth; physiological response

\section{Introduction}

Silicon (Si) is a beneficial element for plants and is ranked as the second most abundant element at $28 \%$ in the Earth's crust following oxygen [1,2]. The Si content of soil ranges from $1-45 \%$ depending on soil type, but $\mathrm{Si}$ is usually scarcely soluble, and its availability for plant uptake is limited [3]. A long period of intensive plant cultivation leads to the deprivation of soil Si, subsequently resulting in insufficient $\mathrm{Si}$ to sustain productive agriculture $[4,5]$. Subtropical and tropical agriculture are typically low in available Si, and rational Si fertilization could enhance crop yield [4]. In plants, silicon deficiency affects the development of strong leaves, stems, and roots. Rice with silicon deficiency is susceptible 
to fungal and bacterial diseases, as well as insect pests. The photosynthetic activity, growth, and grain yield are reduced [6].

The potential of $\mathrm{Si}$ in improving growth and yield and in alleviating the negative effects of biotic and abiotic stresses has been studied in multiple crops including rice, tomato, sugarcane, and wheat $[4,7-11]$. Plants absorb Si from the soil solution in the form of monosilicic acid, also called orthosilicic acid $\left(\mathrm{H}_{4} \mathrm{SiO}_{4}\right)$. On average, plants absorb $50-200 \mathrm{~kg} \mathrm{Si} \cdot \mathrm{ha}^{-1}$ [12]. However, the absorption ability of plants differs greatly among species. According to Si concentrations found in the tissues, plants can be classified as low accumulators $(<0.1 \% \mathrm{Si})$, intermediary accumulators $(1 \% \mathrm{Si})$, and high accumulators (up to $5 \% \mathrm{Si}$ ) [13]. In general, monocots are classified as either intermediate or high accumulators [4]. Most dicots are unable to accumulate Si and belong to the low accumulator classification. However, some dicots of the Asteraceae, Urticaceae, and Cucurbitaceae families are known to benefit from $\mathrm{Si}$ fertilizer, indicating that $\mathrm{Si}$ is absorbed and accumulated in the tissues of these species [14-16].

The beneficial effects of Si on plant growth, productivity, photosynthesis, balanced nutrient availability, and the mechanisms for reactive oxygen species scavenging have been demonstrated in numerous studies $[17,18]$. Thus, the application of Si has been widely implemented on various crops to alleviate the deleterious effects of water, salt, and heavymetal stresses, as well as protect against pest infestation and disease [1,7,9-11,18-21]. Si has been reported to promote stem strength by increasing lignin accumulation. In rice, stem strengthening helps to reduce lodging, thus preventing mutual shading, maintaining canopy photosynthesis, and consequently improving productivity [20,22]. Ahmad and Haddad [19] demonstrated that $\mathrm{Si}$ application positively influenced the antioxidant system in Triticum aestivum plants. Song et al. [23] reported that leaf chloroplast was disordered and chlorophyll content was reduced under high-Zn stress, which were counteracted by the addition of Si. An interaction between Si and nitrogen and an increase in the levels of chlorophyll $a$ in Oryza sativa plants were reported by Âvila et al. [24]. Si has been proven to mediate plant defense against insect and pest infestation. Amorphous Si deposition in plant tissues acts as a physical barrier, contributing to increased rigidity and abrasiveness of plants, thus enabling plants to become less digestible for insects [25-27]. Additionally, in several species, $\mathrm{Si}$ appears to increase the level of proline and glycine betaine concentrations under drought and salinity stresses to attenuate their negative impacts $[28,29]$. However, studies in drought-stressed maize and salt-stressed borage reported a decrease in glycine betaine $[30,31]$.

Oil palm (Elaeis guineensis Jacq.) is the highest yielding oil crop with an average annual oil yield of $3.3 \mathrm{t} \cdot \mathrm{ha}^{-1}$ [32]. In the beginning, oil palm plantations were centered in tropical areas with the optimal conditions for oil palm to grow [33]. Demand for palm oil has greatly increased over the past few decades because of numerous benefits and its applications in food and nonfood industries. To match the growing demand, there has been an expansion of oil palm plantations, but protected areas and other existing land uses have been major limitations [34]. As a perennial crop which generally produces ongoing fruit for up to 30 years, constant high yield is desired. Factors determining yield, i.e., varieties planted, available rain and fertilization must be taken into account. Sufficient nutrition is necessary during the growth and development stages of the oil palm, since nutrient uptake establishes the plant's production potential [33]. In addition to essential nutrients, other elements such as sodium ( $\mathrm{Na}$ ), silicon $(\mathrm{Si})$, and cobalt $(\mathrm{Co})$ have been applied in some species to promote plant growth and development [35]. According to Munevar and Romeo [36] who assessed oil palm throughout Colombia, Si concentration in oil palm ranges from $0.73 \%$ to $1.71 \%$ in leaf no. 3 and $1.55 \%$ to $4.07 \%$ in leaf no. 17 , indicating $\mathrm{Si}$ accumulation and sensitivity to available Si. However, little is known about the potential effects of Si fertilization on oil palm growth and development, especially without biotic and abiotic stresses. Therefore, in this study, we investigated the beneficial effects of silicon fertilization on the growth and physiological responses of oil palm at the seedling stage under nonstress conditions. The 
results of this research can be advantageous in oil palm nutrition management for nursery establishment and to sustain high yields.

\section{Materials and Methods}

\subsection{Pre-Plantation Soil Analysis}

Topsoil of Hat Yai soil series (clayey, skeletal, kaolinitic, isohyperthermic Typic Paleudults) [37] was obtained from the $0-50 \mathrm{~cm}$ layer of an agriculture field in Songkhla Province. Soil was finely prepared, and plant parts and roots were removed using a $2 \mathrm{~mm}$ sieve. A uniform and homogeneous soil sample was obtained prior to soil filling in planting bags. Soil was airdried and sent for soil analysis to assess soil properties and nutrient concentrations. The texture of the soil was sandy clay loam, and details of soil properties including texture [38], $\mathrm{pH}$, electrical conductivity, total $\mathrm{N}$ [39], available P [40], extractable $\mathrm{K}^{+}$, extractable $\mathrm{Mg}$, extractable Ca, and available Si [41] are presented in Table 1. Available $\mathrm{Si}$ in the planting soil used in this current study was $8.774 \mathrm{mg} \cdot \mathrm{kg}^{-1}$, which was considered to be a low level [4].

Table 1. Pre-plantation physicochemical properties of soil used for the experiments.

\begin{tabular}{|c|c|c|c|}
\hline Properties & $\begin{array}{c}\text { Values/ } \\
\text { Description }\end{array}$ & Methods & References/Instrumen \\
\hline Texture & Sandy clay loam & Hydrometer & Bouyoucos, 1936 [38] \\
\hline $\mathrm{pH}$ & 4.76 & $\mathrm{pH}$ meter, soil $/$ water $=1: 5$ & $\begin{array}{l}\text { Seven Easy } \\
\text { (Mettler Toledo) }\end{array}$ \\
\hline $\begin{array}{l}\text { Electrical } \\
\text { conductivity } \\
\left(\mathrm{ds} \cdot \mathrm{m}^{-1}\right)\end{array}$ & 0.303 & EC meter, soil $/$ water $=1: 5$ & $\begin{array}{l}\text { Seven Easy EC Meter } \\
\text { (Mettler Toledo) }\end{array}$ \\
\hline $\begin{array}{l}\text { Total N } \\
\left(\mathrm{g} \cdot \mathrm{kg}^{-1}\right)\end{array}$ & 0.262 & Kjeldahl method & Kjeldahl, 1883 [39] \\
\hline $\begin{array}{l}\text { Available P } \\
\left(\mathrm{mg} \cdot \mathrm{kg}^{-1}\right)\end{array}$ & 1.729 & $\begin{array}{l}\text { Bray II, molybdenum } \\
\text { blue method }\end{array}$ & Bray, 1945 [40] \\
\hline $\begin{array}{l}\text { Extractable } \mathrm{K}^{+} \\
\left(\mathrm{cmol} \cdot \mathrm{kg}^{-1}\right)\end{array}$ & 0.073 & $\begin{array}{l}1 \mathrm{M}-\mathrm{NH}_{4} \mathrm{OAc}(\mathrm{pH} 7) \text { atomic } \\
\text { absorption spectrophotometry }\end{array}$ & Spectrophotometer \\
\hline $\begin{array}{l}\text { Extractable } \mathrm{Mg} \\
\left(\mathrm{cmol} \cdot \mathrm{kg}^{-1}\right)\end{array}$ & 0.020 & $\begin{array}{l}1 \mathrm{M}-\mathrm{NH}_{4} \mathrm{OAc}(\mathrm{pH} 7) \text { atomic } \\
\text { absorption spectrophotometry }\end{array}$ & Spectrophotometer \\
\hline $\begin{array}{l}\text { Extractable Ca } \\
\left(\mathrm{cmol} \cdot \mathrm{kg}^{-1}\right)\end{array}$ & 0.034 & $\begin{array}{l}1 \mathrm{M}-\mathrm{NH}_{4} \mathrm{OAc}(\mathrm{pH} 7) \text { atomic } \\
\text { absorption spectrophotometry }\end{array}$ & Spectrophotometer \\
\hline $\begin{array}{l}\text { Available Si } \\
\left(\mathrm{mg} \cdot \mathrm{kg}^{-1}\right)\end{array}$ & 8.774 & $\begin{array}{l}\text { Yellow molybdenum } \\
\text { blue method }\end{array}$ & Estefan et al., 2013 [41] \\
\hline
\end{tabular}

\subsection{Seedling Transplantation and Adaptation}

Seeds of the oil palm Tenera variety, a hybrid between Dura and Pisifera widely grown in the oil palm industry [33], were germinated in seedling trays. Sandy clay loam soil was filled in black plastic planting bags of $40 \times 45 \mathrm{~cm}$ size. Four month old seedlings were transplanted in planting bags as single seedlings per bag, and the bags were placed at $30 \mathrm{~cm}$ plant-to-plant and row-to-row distance in sheds located the Faculty of Natural Resources, Prince of Songkla University, Hat Yai, Thailand. Plants were manually irrigated on daily basis, and 1.5 L of water per bag was applied to maintain the water content near to field capacity and avoid water stress. Moreover, $7 \mathrm{~g}$ of N-P-K (15-09-15) fertilizer not containing any $\mathrm{Si}$ was applied to each planting bag twice a month to help seedling establishment and nursery adaptation. Emerging weeds were manually removed. A net was placed to protect oil palm seedlings from pests, and daily monitoring for disease was performed during the experiment. 


\subsection{Treatment Application}

Planting bags containing 4 month old single seedlings per planting bag were arranged using a completely randomized design (CRD) with 18 replications in the greenhouse. Calcium silicate $\left(\mathrm{Ca}_{2} \mathrm{SiO}_{4}\right.$ from Sigma-Aldrich, St. Louis, $\mathrm{MO}$, USA) powder was used as the $\mathrm{Si}$ fertilizer source. The water solubility of the $\mathrm{Ca}_{2} \mathrm{SiO}_{4}$ used was $0.26 \mathrm{~g} / \mathrm{L}$ at $20^{\circ} \mathrm{C}$. Plants were subjected to four treatments: (i) $0 \mathrm{~g} \mathrm{Ca}_{2} \mathrm{SiO}_{4}$ (T0), (ii) $0.5 \mathrm{~g} \mathrm{Ca}_{2} \mathrm{SiO}_{4} \cdot \mathrm{plant}^{-1} \cdot \mathrm{month}^{-1}$ (T1), (iii) $3.5 \mathrm{~g} \mathrm{Ca}_{2} \mathrm{SiO}_{4} \cdot$ plant $^{-1} \cdot \mathrm{month}^{-1}$ (T2), and (iv) $7.0 \mathrm{~g} \mathrm{Ca}_{2} \mathrm{SiO}_{4} \cdot$ plant $^{-1} \cdot \mathrm{month}^{-1}$ (T3). $\mathrm{Ca}_{2} \mathrm{SiO}_{4}$ was applied at $10 \mathrm{~cm}$ soil depth from the base of the plants, every month for four consecutive months.

\subsection{Data Collection}

Nondestructive data including stem diameter, plant height, and leaf length were recorded on 10 reserved seedlings from each treatment before treatment (0 DAT), as well as 60 (60 DAT) and 120 days after treatment (120 DAT). Stem diameter was recorded by measuring the circumference of the base of the stem near the soil surface in the planting bag. Plant height was recorded as the length of oil palm plants from soil surface to the joint of topmost leaf. Leaf length was recorded from the base of the leaf to the tip. A portable photosynthesis measurement system LCpro-SD (ADC BioScientific Ltd., Hoddesdon, UK) was used to record the photosynthetic rate at the third fully expanded leaf in each treatment between 9:00 and 10:00 a.m. for each recording interval. Leaf angle and leaf thickness were measured using a MultispeQ device at the third fully expanded leaf in each treatment. The relative rate of growth in stem diameter, leaf length, and plant height was calculated using a modification of the formula proposed by Hoffmann and Poorter [42].

$$
\text { Relative growth rate }(\mathrm{RGR})=\frac{\left(\ln \mathrm{A}_{t}-\ln \mathrm{A}_{i}\right)}{\mathrm{t}_{2}-\mathrm{t}_{1}},
$$

where " $\ln$ " is the natural logarithm, " $\mathrm{A}_{t}$ " is the reference value for specific attributes and units at $60 \mathrm{DAT}$ and $120 \mathrm{DAT}$, and " $\mathrm{A}_{i}$ " is the reference value for specific attribute and units at 0 DAT; " $\mathrm{t}_{2}$ " refers to 60 DAT and 120 DAT, while " $\mathrm{t}_{1}$ " refers to 0 DAT.

Destructive data including fresh weight and dry weight of four oil palm seedlings from each treatment were recorded at 0 DAT, 60 DAT, and 120 DAT. At 120 DAT, four oil palm seedlings were taken from those reserved for nondestructive data collection. Plant samples were first separated into leaves, roots, and stems to record fresh weight and were then kept in the oven for various time intervals at $75^{\circ} \mathrm{C}$ until a constant weight was observed. The foliar content of chlorophyll $a$, the main pigment that participates directly in harvesting light energy for photosynthesis in plants [43], was measured from three randomly selected oil palm seedlings at the third fully expanded leaf in each treatment. Leaves were drilled into circular discs with an area of 0.84 square centimeters. Leaf samples were then placed into a glass tube filled with $4 \mathrm{~mL}$ of DMF ( $N, N$-dimethylformamide), and tubes were covered and stored in the dark for $24 \mathrm{~h}$ at $4{ }^{\circ} \mathrm{C}$ to prevent chlorophyll contents from being damaged by light. The DMF solution was used to measure the absorbance at 647 and $664 \mathrm{~nm}$ wavelengths with a spectrophotometer using pure DMF solution as a reference. The recorded absorbance was used to calculate the chlorophyll $a$ content according to Equation (2).

$$
\text { Chlorophyll } a=\left[-2.99\left(\mathrm{~A}_{647}\right)+12.64\left(\mathrm{~A}_{664}\right)\right] \times \frac{\text { vol }}{\mathrm{X} \times \text { Area } \times 100},
$$

where $A_{647}$ is the absorbance at a wavelength of $647 \mathrm{~nm}, \mathrm{~A}_{664}$ is the absorbance at a wavelength of $664 \mathrm{~nm}$, vol is the volume of DMF used to extract chlorophyll $(\mathrm{mL})$, and $\mathrm{X}$ is the dilution factor. 


\subsection{Determination of Silicon and Nitrogen Contents in Oil Palm Seedlings}

Plant samples were obtained for silicon and nitrogen content analysis to observe the variations in nutrient absorbance under various treatments. The silicon concentration in plant parts was analyzed using the molybdenum blue method [41] to observe silicon accumulation in plants. The distribution of silicon in different parts of plants was calculated using Equation (3). The Kjeldahl method [39] was used to determine the nitrogen content of oil palm seedlings.

Si distribution $=($ Si concentration in plant part $/$ Total Si concentration $) \times 100$

\subsection{Statistical Analysis}

Observed data were statistically analyzed using the Statistix 8.1 package (Analytical software, Tallahassee, FL, USA) to study the impact and the significance of fertilization treatments. Means were compared using Fisher's least significant difference (LSD) method at a 95\% confidence level. "Corr" and Corrplot packages [44] of R program were used to compute Pearson's correlation matrices and visuals for various attributes as described by Hussain et al. [45].

\section{Results}

\subsection{Accumulation and Distribution of Si in Oil Palm Seedlings}

The concentration of silicon ( $\mathrm{Si}$ ) was highest in leaf followed by root and stem at 120 DAT (Table 2). Si-treated soil resulted in a gradual increase in Si content in stem and leaf, ranging from $0.17 \%$ to $0.24 \%$ and from $0.63 \%$ to $0.89 \%$, respectively. Si concentration in the root was not significantly different in oil palm seedlings grown under nontreated and $\mathrm{Si}-$ treated soil. The silicon percentage in root ranged from $0.40 \%$ to $0.45 \%$.

Table 2. Silicon concentration in the root, stem, and leaf of oil palm after 4 months of calcium silicate application.

\begin{tabular}{cccc}
\hline \multirow{2}{*}{ Si Fertilization Treatments } & \multicolumn{3}{c}{ Si Concentration (\% Dry Weight) } \\
\cline { 2 - 4 } & Root & Stem & Leaf \\
\hline T0 & $0.45 \pm 0.01$ & $0.17 \pm 0.09 \mathrm{~b}$ & $0.66 \pm 0.02 \mathrm{~b}$ \\
T1 & $0.44 \pm 0.02$ & $0.22 \pm 0.01 \mathrm{ab}$ & $0.63 \pm 0.05 \mathrm{~b}$ \\
T2 & $0.45 \pm 0.02$ & $0.25 \pm 0.01 \mathrm{a}$ & $0.74 \pm 0.02 \mathrm{ab}$ \\
T3 & $0.40 \pm 0.05$ & $0.24 \pm 0.01 \mathrm{a}$ & $0.89 \pm 0.04 \mathrm{a}$ \\
\hline F-test & ns & $*$ & $*$ \\
CV $(\%)$ & 11.60 & 7.80 & 8.54 \\
\hline Data are represented as means + standard errors; ns indicates non-significant; indicates significant at $p \leq 0.01$.
\end{tabular}

Different letters in the same column indicate significant differences according to the LSD test at $p \leq 0.01(n=4)$.

Generally, Si accumulation increased significantly with seedling age regardless of Si fertilizer treatment (Figure 1A-D). Leaves accumulated the highest amount of Si ranging from 124-163 g.plant ${ }^{-1}$ and $494-736 \mathrm{~g} \cdot$ plant $^{-1}$ at 60 DAT and 120 DAT, respectively (Figure 1C). In stem, Si accumulation of 36-44 g.plant ${ }^{-1}$ and $94-134 \mathrm{~g} \cdot$ plant $^{-1}$ was observed at 60 DAT and $120 \mathrm{DAT}$, respectively (Figure 1B). Si accumulation in root was the lowest compared to accumulation in other tissues at $60 \mathrm{DAT}$, with the range of $24-43 \mathrm{~g} \cdot$ plant $^{-1}$ (Figure 1A). However, at 120 DAT, a range of 141-172 g.plant ${ }^{-1}$ was found in oil palm root, surpassing $\mathrm{Si}$ accumulation in the stem. Considering the whole plant, Si accumulation was approximately $121 \mathrm{~g} \cdot$ plant $^{-1}$ prior to the start of Si treatment. Si accumulation then increased to 172-249 g. plant ${ }^{-1}$ and 740-1040 g. plant ${ }^{-1}$ at 60 DAT and 120 DAT, respectively (Figure 1D). According to the results, application of $\mathrm{Si}$ fertilizer to oil palm seedlings generally enhanced $\mathrm{Si}$ accumulation in the shoot, stem, and total plant but not in the root. Si fertilization of 3.5 and $7.0 \mathrm{~g} \cdot$ plant $^{-1} \cdot$ month $^{-1}$ significantly increased the stem, leaf, and total Si accumulation in oil palm seedlings starting from 60 DAT. 

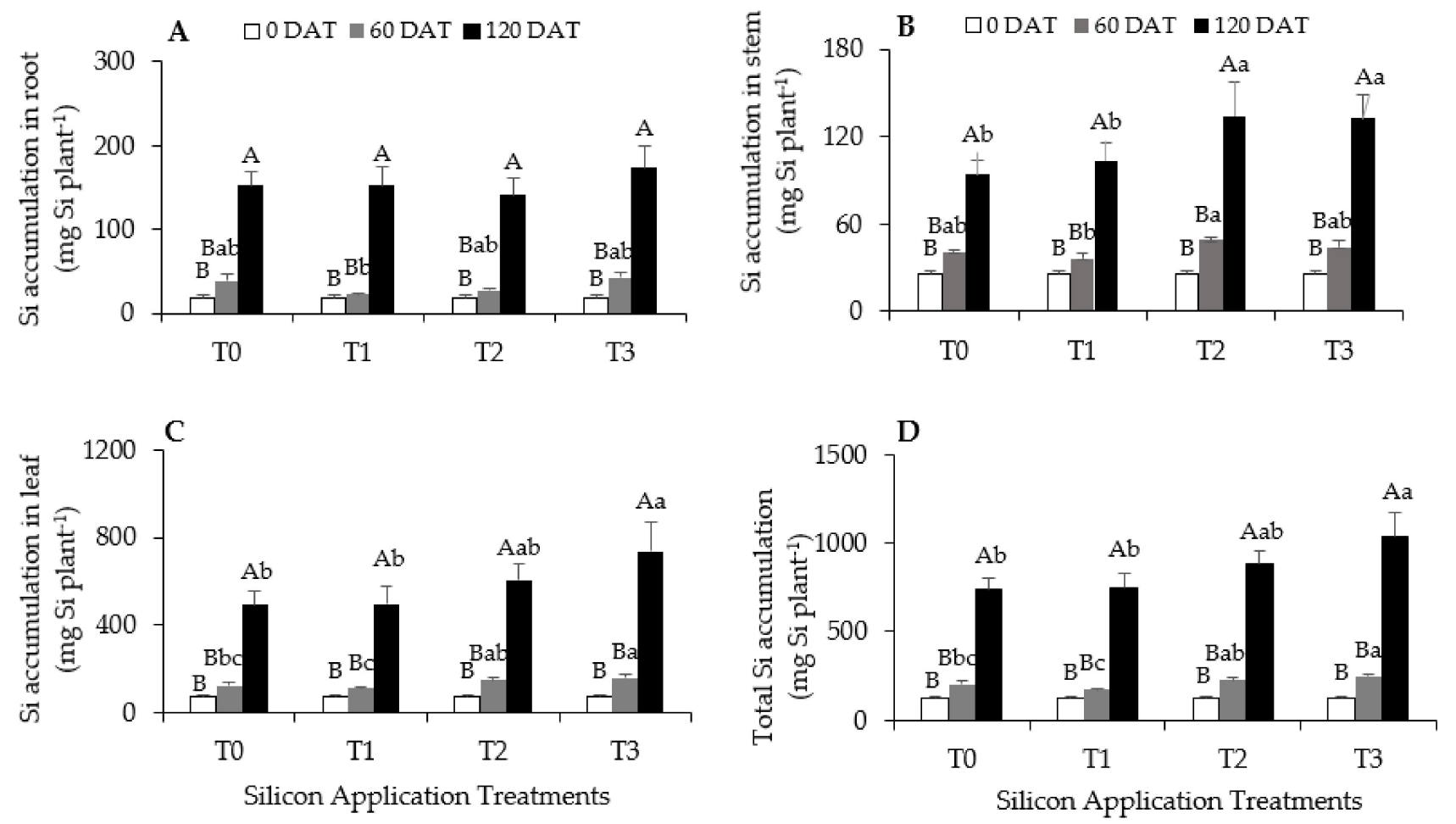

Figure 1. Silicon accumulation in the root (A), stem (B), leaf (C), and total plant (D). Data represent the means, and error bars represent the standard errors of the means. Different uppercase letters indicate significant differences in silicon accumulation at 0, 60, and 120 days after treatment (DAT), and different lowercase letters indicate significant differences in silicon accumulation in oil palm seedlings treated with different levels of calcium silicate according to the LSD test at $p \leq 0.01$ $(n=4)$. T0, T1, T2, and T3 are Si treatments of oil palm seedlings using $0,0.5,3.5$, and $7.0 \mathrm{~g}$ $\mathrm{Ca}_{2} \mathrm{SiO}_{4} \cdot$ plant $^{-1} \cdot$ month $^{-1}$, respectively.

\subsection{Positive Impacts of Silicon on Oil Palm Growth}

Application of Si fertilizer stimulated the oil palm growth. The stem, leaf, and total plant biomass of oil palm seedlings was significantly promoted by 3.5 and $7.0 \mathrm{~g}$ Si fertilizer. plant $^{-1} \cdot$ month $^{-1}$ treatments (Figures 2 and 3A-D). Root biomass, however, was not affected by Si fertilization. Overall, root dry weight increased 1.56- and 5.30-fold at 60 and 120 DAT, respectively, regardless of Si fertilizer application (Figure 3A). Stem dry weight increased 1.86- and 6.05-fold at 60 and 120 DAT, respectively, without addition of Si fertilizer. Similarly, 1.58- and 5.68-fold increases at 60 and 120 DAT, respectively, were observed in oil palm treated with $0.5 \mathrm{~g} \mathrm{Si} \mathrm{fertilizer \cdot plant}{ }^{-1} \cdot$ month $^{-1}$. A significant increase in stem dry weight with Si supplementation was noted at 60 DAT. Application of Si fertilizer at 3.5 and $7.0 \mathrm{~g} \cdot$ plant $^{-1} \cdot$ month $^{-1}$ resulted in 1.95- and 2.07-fold increases, respectively, in stem dry weight at 60 DAT and 7.34- and 7.59-fold increases, respectively, in stem dry weight at 120 DAT (Figure 3B). Similar results were observed for leaf and total plant biomass in oil palm treated with Si fertilizer at 3.5 and $7.0 \mathrm{~g} \cdot$ plant $^{-1} \cdot \mathrm{month}^{-1}$. At 60 DAT, leaf biomass increased 1.84- and 1.85-fold when silicon fertilizer at 3.5 and $7.0 \mathrm{~g} \cdot$ plant $^{-1} \cdot$ month $^{-1}$ was applied, respectively, compared to the 1.58 -fold increase in the control treatment. More notable effects of Si fertilizer were demonstrated at 120 DAT. Specifically, 6.38- and 6.39-fold increases in accumulation were observed in leaf biomass of oil palm seedlings with 3.5 and $7.0 \mathrm{~g} \mathrm{Si} \cdot$ plant $^{-1} \cdot \mathrm{month}^{-1}$, respectively, at $120 \mathrm{DAT}$, whereas oil palm seedlings without Si fertilization and with $0.5 \mathrm{~g} \mathrm{Si} \cdot$ plant $^{-1} \cdot \mathrm{month}^{-1}$ exhibited 5.2and 4.68-fold increases in leaf dry weight (Figure 3C). 


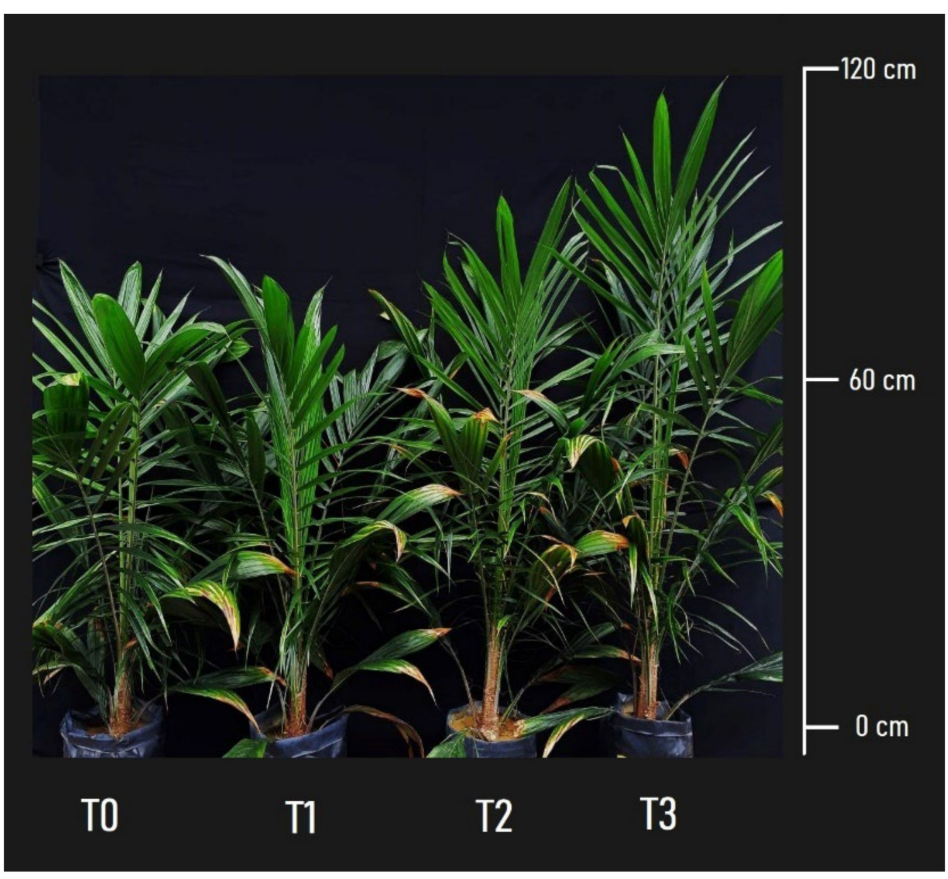

Figure 2. Positive impact of silicon fertilization on growth of oil palm seedlings at 120 days after treatment. T0, T1, T2, and T3 are Si treatments of oil palm seedlings using 0, 0.5, 3.5, and $7.0 \mathrm{~g}$ $\mathrm{Ca}_{2} \mathrm{SiO}_{4} \cdot$ plant $^{-1} \cdot \mathrm{month}^{-1}$, respectively.
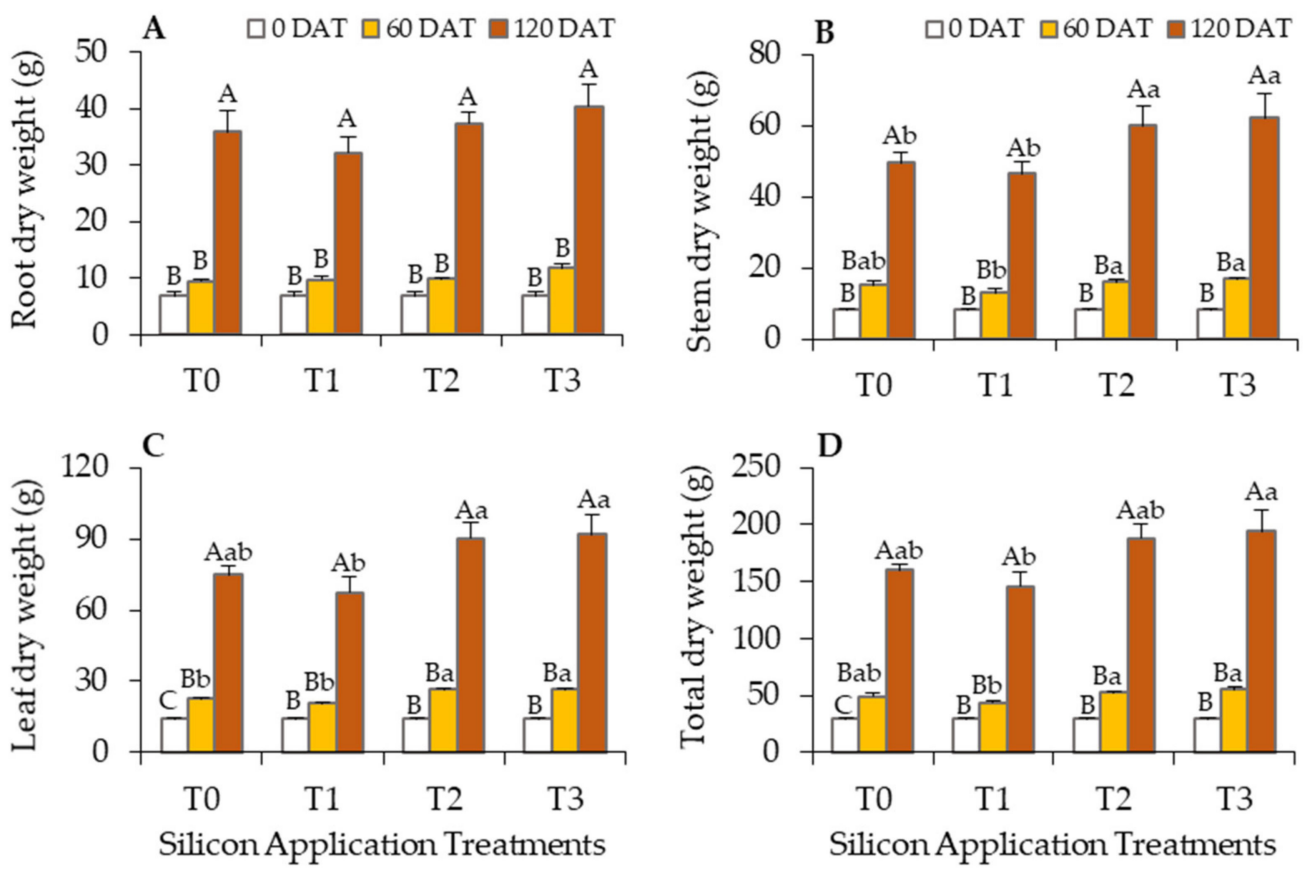

Figure 3. Root (A), stem (B), leaf (C), and total plant (D) dry weight. Data represent the means, and error bars represent the standard errors of the means. Different uppercase letters indicate significant differences in silicon accumulation at 0, 60, and 120 days after treatment (DAT), and different lowercase letters indicate significant differences in silicon accumulation in oil palm seedlings treated with different levels of calcium silicate according to the LSD test at $p \leq 0.01(n=4)$. T0, T1, T2, and T3 are $\mathrm{Si}$ treatments of oil palm seedlings using $0,0.5,3.5$, and $7.0 \mathrm{~g} \mathrm{Ca}_{2} \mathrm{SiO}_{4} \cdot$ plant $^{-1} \cdot \mathrm{month}^{-1}$, respectively.

Similar patterns in the dry mass accumulation of oil palm seedlings treated with $\mathrm{Si}$ fertilizer were noticed for fresh weight (Figure 4). Si fertilization at $0.5 \mathrm{~g} \cdot \mathrm{plant}^{-1} \cdot \mathrm{month}^{-1} \mathrm{did}$ not noticeably change the fresh weight accumulation in oil palm seedlings. The stem and 
leaf but not the root of oil palm seedlings treated with 3.5 and $7.0 \mathrm{~g} \cdot \mathrm{plant}^{-1} \cdot \mathrm{month}^{-1} \mathrm{ex}-$ hibited a significant increase when compared with the control at 60 and 120 DAT (Figure 4). Stem fresh weight increased 1.67-, 1.52-, 2.03-, and 1.76-fold at 60 DAT following control, $0.5,3.5$, and $7.0 \mathrm{~g} \mathrm{Si} \cdot$ plant $^{-1}$. month $^{-1}$ treatments, respectively, in contrast to 5.44-, 5.40-, 6.93-, and 6.94-fold, respectively, at 120 DAT (Figure 4B). A significant increase in the leaf fresh weight was noted when at least $3.5 \mathrm{~g} \mathrm{Si} \cdot$ plant $^{-1} \cdot \mathrm{month}^{-1}$ was applied to oil palm seedlings. In the control treatment, leaf fresh weight increased 1.96- and 5.50-fold at 60 and 120 DAT, respectively, whereas Si fertilization rates of 3.5 and $7.0 \mathrm{~g} \cdot$ plant $^{-1} \cdot \mathrm{month}^{-1}$ significantly stimulated2.46- and 2.34-fold increases in leaf fresh weight, respectively, at 60 DAT and 6.61- and 6.67-fold increases in leaf fresh weight, respectively, at 120 DAT (Figure 4C).
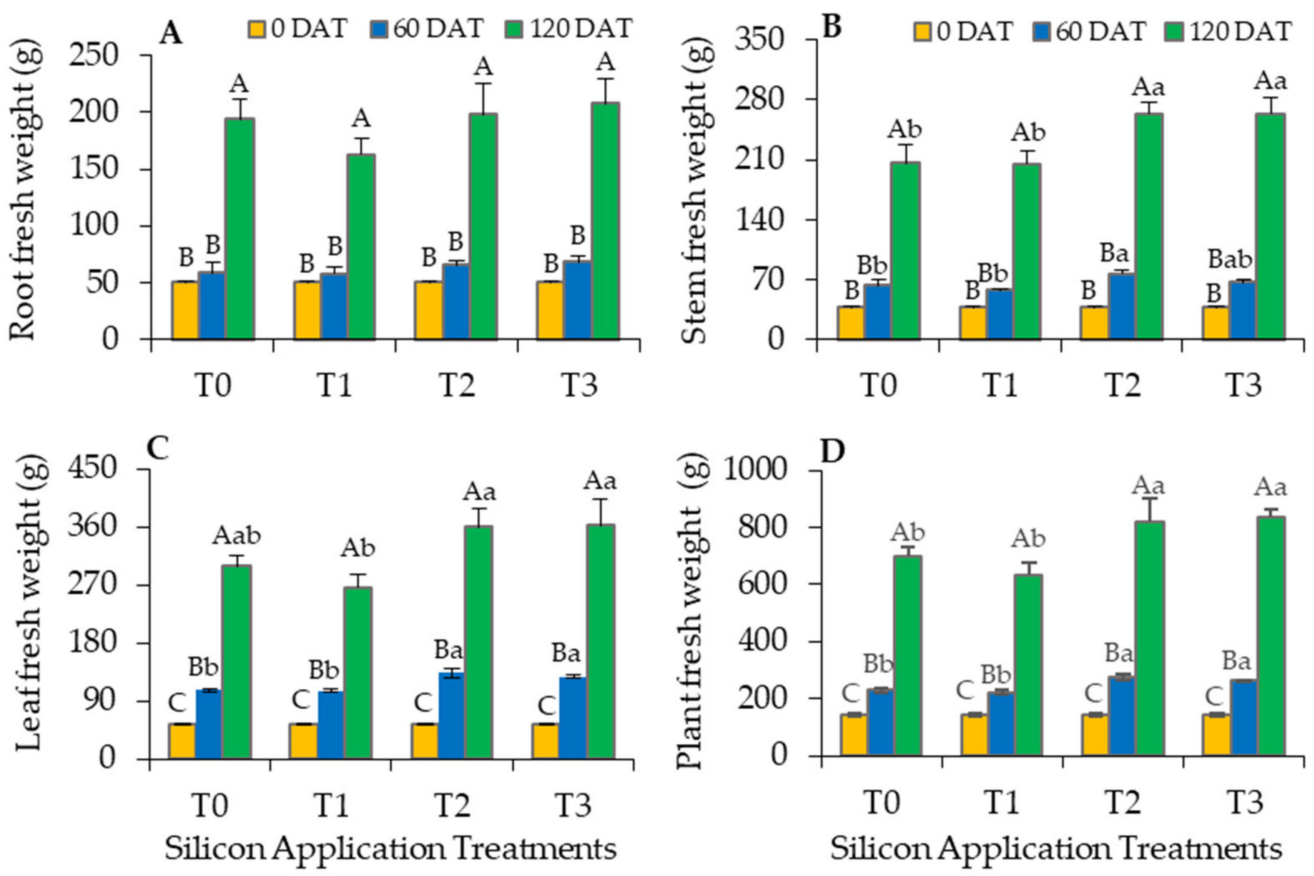

Figure 4. Root (A), stem (B), leaf (C), and total plant (D) fresh weight. Data represent the means, and error bars represent the standard errors of the means. Different uppercase letters indicate significant differences in silicon accumulation at 0,60, and 120 days after treatment (DAT), and different lowercase letters indicate significant differences in silicon accumulation in oil palm seedlings treated with different levels of calcium silicate according to the LSD test at $p \leq 0.01(n=4)$. T0, T1, T2, and T3 are Si treatments of oil palm seedlings using $0,0.5,3.5$, and $7.0 \mathrm{~g} \mathrm{Ca}_{2} \mathrm{SiO}_{4} \cdot$ plant $^{-1} \cdot \mathrm{month}^{-1}$, respectively.

Si fertilization demonstrated positive effects on the relative growth rate of oil palm stem diameter, leaf length, and plant height (Figure 5). The relative growth rate of stem diameter was generally higher at $60 \mathrm{DAT}$ as compared to $120 \mathrm{DAT}$ with and without $\mathrm{Si}$ fertilization. The maximum relative growth rate in stem diameter was observed in oil palm seedlings treated with $7.0 \mathrm{~g} \mathrm{Ca}_{2} \mathrm{SiO}_{4} \cdot$ plant $^{-1} \cdot$ month $^{-1}$ at $60 \mathrm{DAT}$. The increase in relative growth rate of stem diameter was then abated but still stimulated by the addition of $\mathrm{Si}$ fertilizer at 120 DAT (Figure 5A).

Similar trends were demonstrated in the relative growth rate of leaf length and plant height. At $60 \mathrm{DAT}$, the relative leaf length rate of oil palm seedlings treated with $7.0 \mathrm{~g}$ $\mathrm{Ca}_{2} \mathrm{SiO}_{4} \cdot$ plant $^{-1} \cdot$ month $^{-1}$ was significantly higher as compared to other treatments. At 120 DAT, application of both $3.5 \mathrm{~g}$ and $7.0 \mathrm{~g} \mathrm{Ca}_{2} \mathrm{SiO}_{4} \cdot$ plant $^{-1} \cdot$ month $^{-1}$ considerably increased the relative leaf length rate. Under control conditions, the relative leaf length rate at 120 DAT was slightly lower than that at 60 DAT (Figure 5B). The relative plant height rate was also positively affected by $\mathrm{Si}$ fertilization. Although the stimulating effects were not 
observed $60 \mathrm{DAT}$, a significant increase in the relative plant height rate of oil palm seedlings supplemented with $7.0 \mathrm{~g} \mathrm{Ca}_{2} \mathrm{SiO}_{4} \cdot \mathrm{plant}^{-1} \cdot \mathrm{month}^{-1}$ was detected 120 DAT (Figure 5C).

A

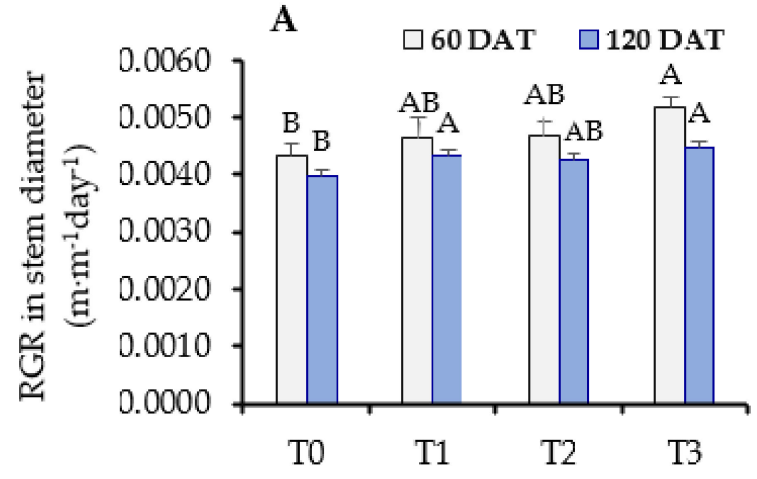

Silicon Application Treatments
B

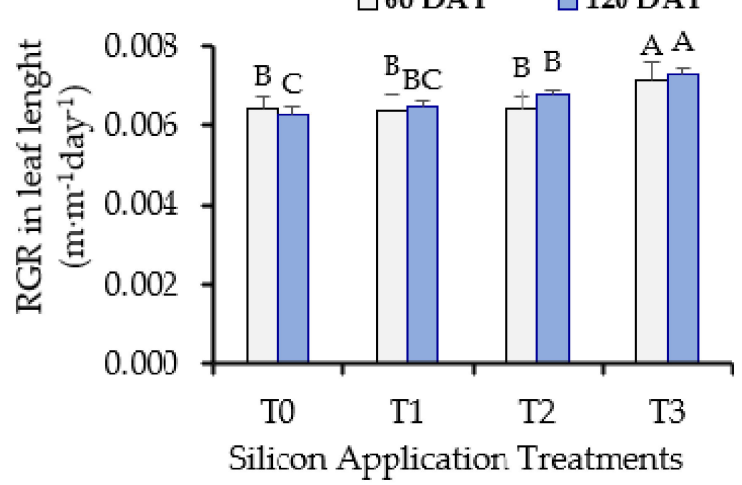

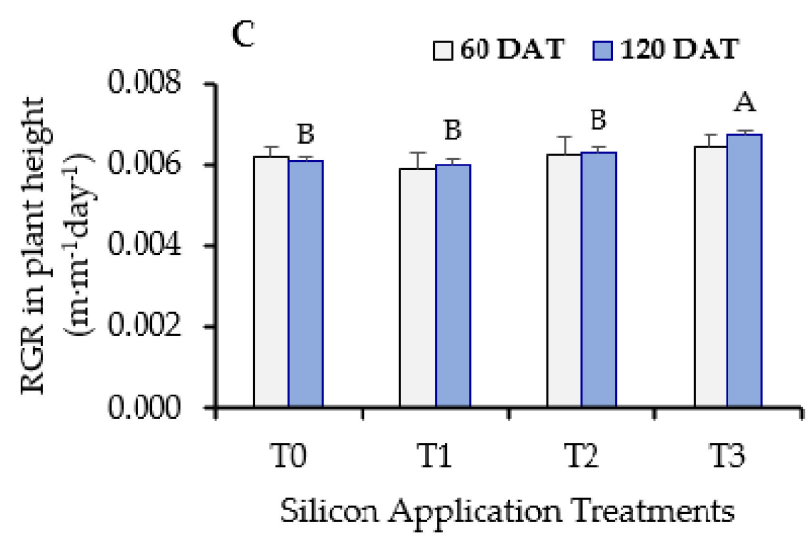

Figure 5. Relative growth rate (RGR) of stem diameter (A), leaf length (B), and plant height (C). Data represent the means, and error bars represent the standard errors of the means. Different uppercase letters indicate significant differences in silicon accumulation at 0, 60, and 120 days after treatment (DAT) in oil palm seedlings treated with different levels of calcium silicate according to the LSD test at $p \leq 0.01(n=10)$. T0, T1, T2, and T3 are Si treatments of oil palm seedlings using $0,0.5,3.5$, and $7.0 \mathrm{~g} \mathrm{Ca}_{2} \mathrm{SiO}_{4} \cdot$ plant $^{-1} \cdot$ month $^{-1}$, respectively.

\subsection{Effects of Silicon Fertilization on Physiological Responses of Oil Palm Seedlings}

In the present study, the stimulating effects of Si fertilization on chlorophyll $a$ content and photosynthesis were clearly demonstrated (Figure 6). Starting from 60 DAT, the chlorophyll $a$ content and photosynthetic rate following treatments with 3.5 and $7.0 \mathrm{~g}$ $\mathrm{Ca}_{2} \mathrm{SiO}_{4} \cdot$ plant $^{-1} \cdot$ month $^{-1}$ were significantly higher than those following control and $0.5 \mathrm{~g}$ $\mathrm{Ca}_{2} \mathrm{SiO}_{4} \cdot$ plant $^{-1} \cdot$ month $^{-1}$ treatments. The chlorophyll $a$ content was increased 1.14- and 1.07-fold by the 3.5 and $7.0 \mathrm{~g} \mathrm{Ca}_{2} \mathrm{SiO}_{4}$. plant $^{-1}$. month $^{-1}$ treatments, respectively, compared to the control at 60 DAT and increased 1.20- and 1.13-fold, respectively, at 120 DAT (Figure 6A). A significant increase in photosynthetic rate were observed along with an increase in chlorophyll $a$ content. At $60 \mathrm{DAT}$, the photosynthetic rate of oil palm seedlings following 3.5 and $7.0 \mathrm{~g} \mathrm{Ca}_{2} \mathrm{SiO}_{4} \cdot$ plant $^{-1} \cdot$ month $^{-1}$ treatments were increased 1.09- and 1.08 -fold, respectively, compared to the control. Similarly, at 120 DAT, 3.5 and $7.0 \mathrm{~g}$ $\mathrm{Ca}_{2} \mathrm{SiO}_{4} \cdot$ plant $^{-1} \cdot$ month $^{-1}$ treatments increased the photosynthetic rate 1.05- and 1.04-fold, respectively, compared to the nontreated seedlings (Figure 6B). 

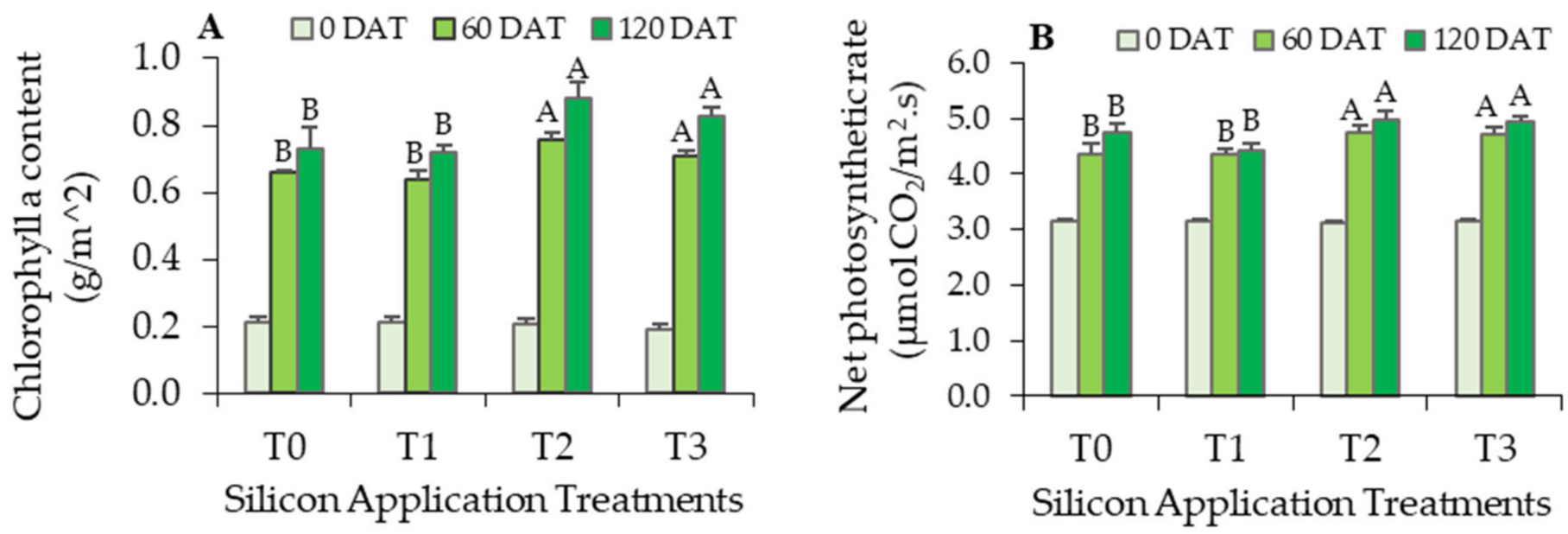

Figure 6. Chlorophyll $a$ content (A) and net photosynthetic rate (B). Data represent the means, and error bars represent the standard errors of the means. Different uppercase letters indicate significant differences in silicon accumulation at 0,60 , and 120 days after treatment (DAT) in oil palm seedlings treated with different level of calcium silicate according to the LSD test at $p \leq 0.01$ $(n=3)$. T0, T1, T2, and T3 are Si treatments of oil palm seedlings using $0,0.5,3.5$, and $7.0 \mathrm{~g}$ $\mathrm{Ca}_{2} \mathrm{SiO}_{4} \cdot$ plant $^{-1} \cdot$ month $^{-1}$, respectively.

\subsection{Effects of Silicon Fertilization on Oil Palm Leaf Morphology}

Leaf angle and leaf thickness were measured to elucidate the effects of Si fertilization on leaf morphology (Figure 7). A slight decrease in leaf angle was measured following control and $0.5 \mathrm{~g} \mathrm{Ca}_{2} \mathrm{SiO}_{4} \cdot$ plant $^{-1} \cdot$ month $^{-1}$ treatments, indicating that seedling leaves were less erect, whereas 3.5 and $7.0 \mathrm{~g} \mathrm{Ca}_{2} \mathrm{SiO}_{4} \cdot$ plant $^{-1} \cdot$ month $^{-1}$ treatments led to more upright leaves. At 0 DAT, leaf angle ranged from $44.12^{\circ}$ to $44.6^{\circ}$ in all treatments. At 120 DAT, leaf angle ranged from $44.89^{\circ}$ to $45.08^{\circ}$ in 3.5 and $7.0 \mathrm{~g} \mathrm{Ca}_{2} \mathrm{SiO}_{4} \cdot$ plant $^{-1} \cdot$ month $^{-1}$ treatments, $^{-}$ respectively, in contrast to $43.53^{\circ}$ and $43.45^{\circ}$ in control and $0.5 \mathrm{~g} \mathrm{Ca}_{2} \mathrm{SiO}_{4} \cdot$ plant $^{-1} \cdot \mathrm{month}^{-1}$ treatments, respectively (Figure 7A). However, leaf thickness was not affected by Si fertilization (Figure 7B). Leaves in all treatments increased in thickness with the age of seedlings, exhibiting a similar pattern across treatments. At 0 DAT, leaf thickness was approximately $0.60 \mathrm{~mm}$, and it increased to the range of 0.64 to $0.68 \mathrm{~mm}$ at $60 \mathrm{DAT}$ and to the range of 0.65 to $0.68 \mathrm{~mm}$ at $120 \mathrm{DAT}$ (Figure $7 \mathrm{~B}$ ).

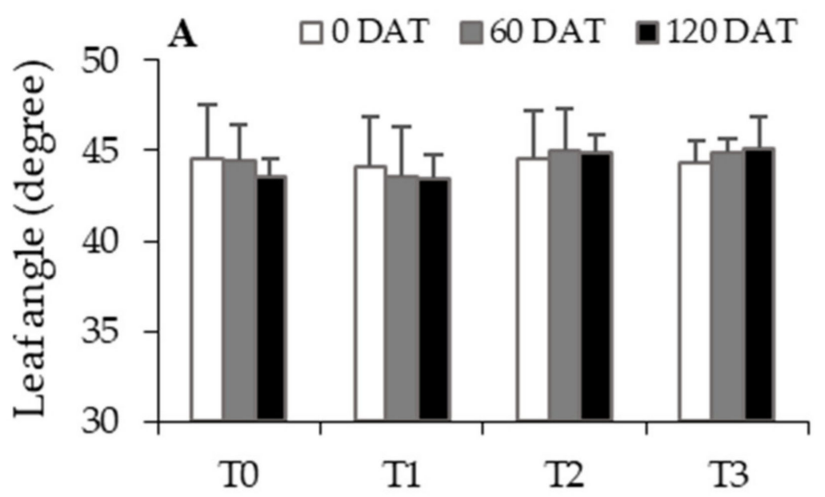

Silicon Application Treatments

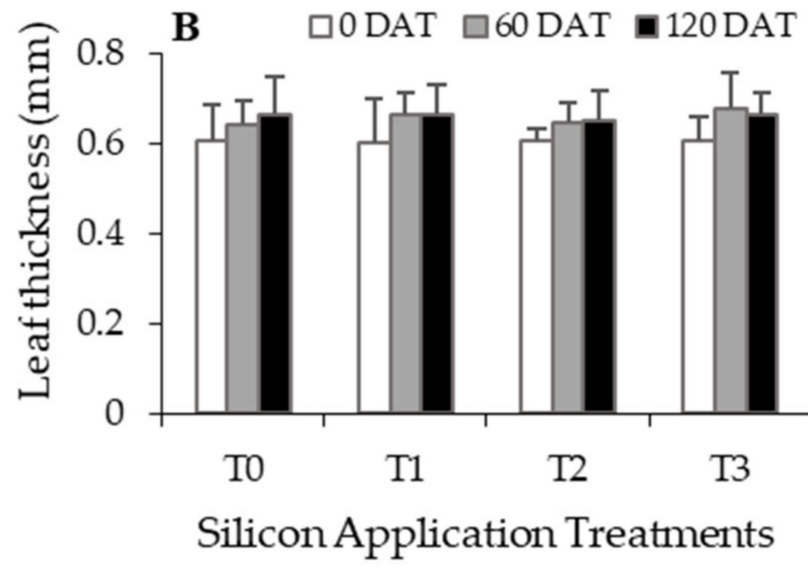

Figure 7. Oil palm leaf angle (A) and leaf thickness (B). Data represent the means, and error bars represent the standard errors of the means. T0, T1, T2, and T3 are Si treatments of oil palm seedlings using $0,0.5,3.5$, and $7.0 \mathrm{~g} \mathrm{Ca}_{2} \mathrm{SiO}_{4} \cdot$ plant $^{-1} \cdot$ month $^{-1}$, respectively. 


\subsection{Effects of Silicon Fertilization on Nitrogen Accumulation in Oil Palm Seedlings}

Oil palm seedlings grown in soil treated with 3.5 and $7.0 \mathrm{~g} \mathrm{Ca}_{2} \mathrm{SiO}_{4} \cdot \mathrm{plant}^{-1} \cdot \mathrm{month}^{-1}$ accumulated considerably higher nitrogen content as compared to the control (Figure 8). Prior to Si treatments, oil palm seedlings contained approximately $0.38 \mathrm{~g} \mathrm{~N} \cdot \mathrm{kg}^{-1}$ dry weight. At 60 DAT, oil palm seedlings without $\mathrm{Si}$ fertilization accumulated $0.82 \mathrm{~g} \mathrm{~N} \cdot \mathrm{kg}^{-1}$ DW, whereas fertilization with $0.5,3.5$, and $7.0 \mathrm{~g} \mathrm{Ca}_{2} \mathrm{SiO}_{4} \cdot$ plant $^{-1} \cdot$ month $^{-1}$ resulted in $0.82,1.08$, and $1.03 \mathrm{~g} \mathrm{~N} \cdot \mathrm{kg}^{-1} \mathrm{DW}$, respectively. At $120 \mathrm{DAT}$, nitrogen accumulation was $2.25,1.87,2.43$, and $2.58 \mathrm{~g} \mathrm{~N} \cdot \mathrm{kg}^{-1} \mathrm{DW}$ following treatment with $0,0.5,3.5$, and $7.0 \mathrm{~g}$ $\mathrm{Ca}_{2} \mathrm{SiO}_{4} \cdot$ plant $^{-1} \cdot$ month $^{-1}$, respectively.

\section{DAT $\square$ 60DAT $\square$ 120DAT}

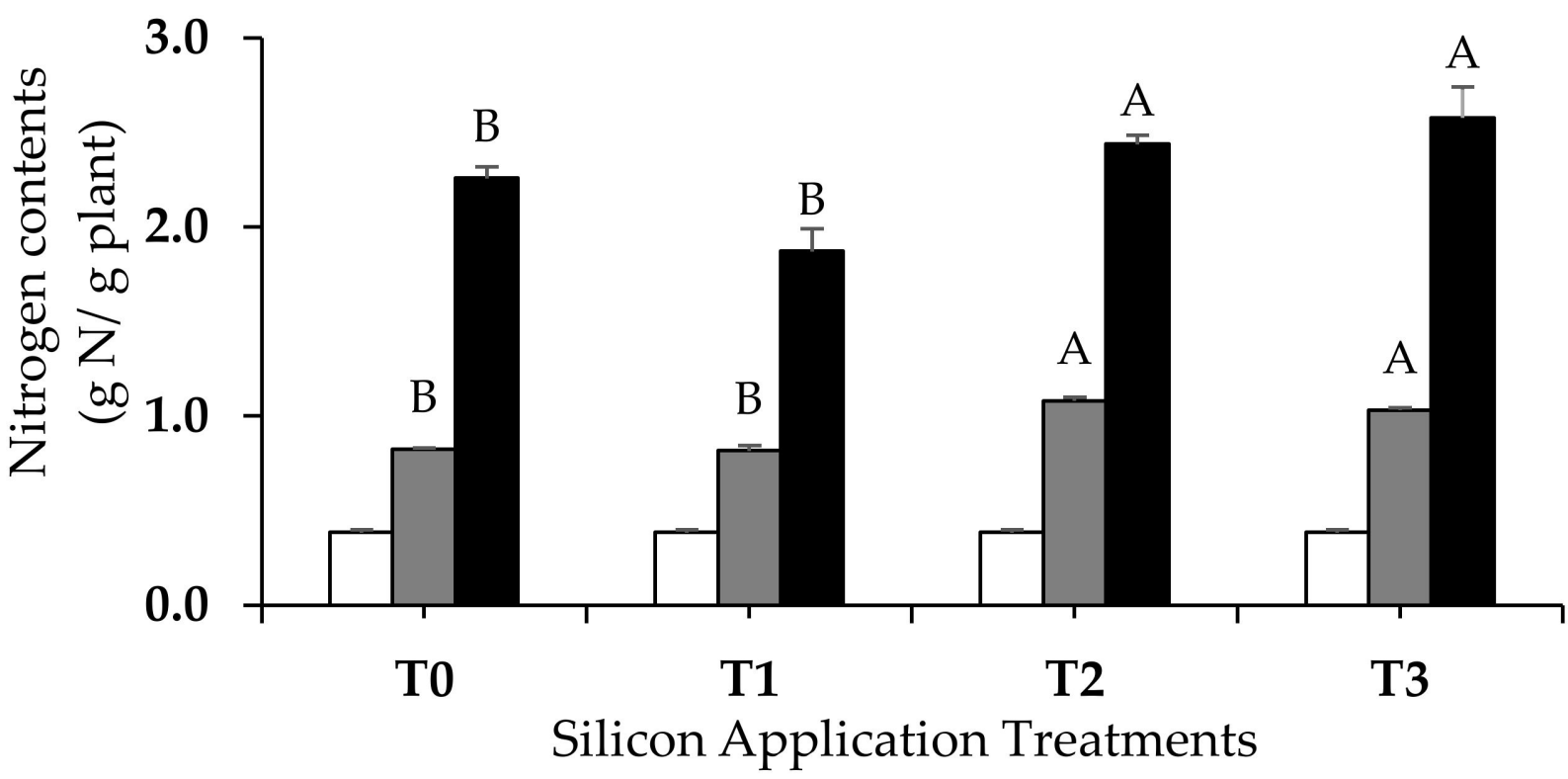

Figure 8. Nitrogen content in oil palm seedlings. Data represent the means, and error bars represent the standard errors of the means. Different uppercase letters indicate significant differences in nitrogen accumulation at 0,60 , and 120 days after treatment (DAT) according to the LSD test at $p \leq 0.01(n=10)$. T0, T1, T2, and T3 are Si treatments of oil palm seedlings using $0,0.5,3.5$, and $7.0 \mathrm{~g}$ $\mathrm{Ca}_{2} \mathrm{SiO}_{4} \cdot$ plant $^{-1} \cdot$ month $^{-1}$, respectively.

\subsection{Correlation Assessment}

The correlation assessment (Pearson's) among various attributes (Figure 9) showed high positive associations between $\mathrm{Si}$ accumulation and total fresh weight (0.99), total dry weight (0.99), and nitrogen content (0.98). A highly positive correlation was also found between nitrogen content and total fresh weight (0.99) and total dry weight (0.99). A positive relationship was detected between silicon accumulation and chlorophyll $a$ content (0.76) and net photosynthesis (0.61). As expected, chlorophyll $a$ content and net photosynthesis were highly correlated (0.91). The high associations among these attributes indicated the positive relationship and beneficial impact of Si fertilization. In contrast, negative associations were observed in terms of relative growth rate between stem diameter and total dry weight $(-0.60)$, stem diameter and total fresh weight $(-0.59)$, and stem diameter and nitrogen content $(-0.57)$. 


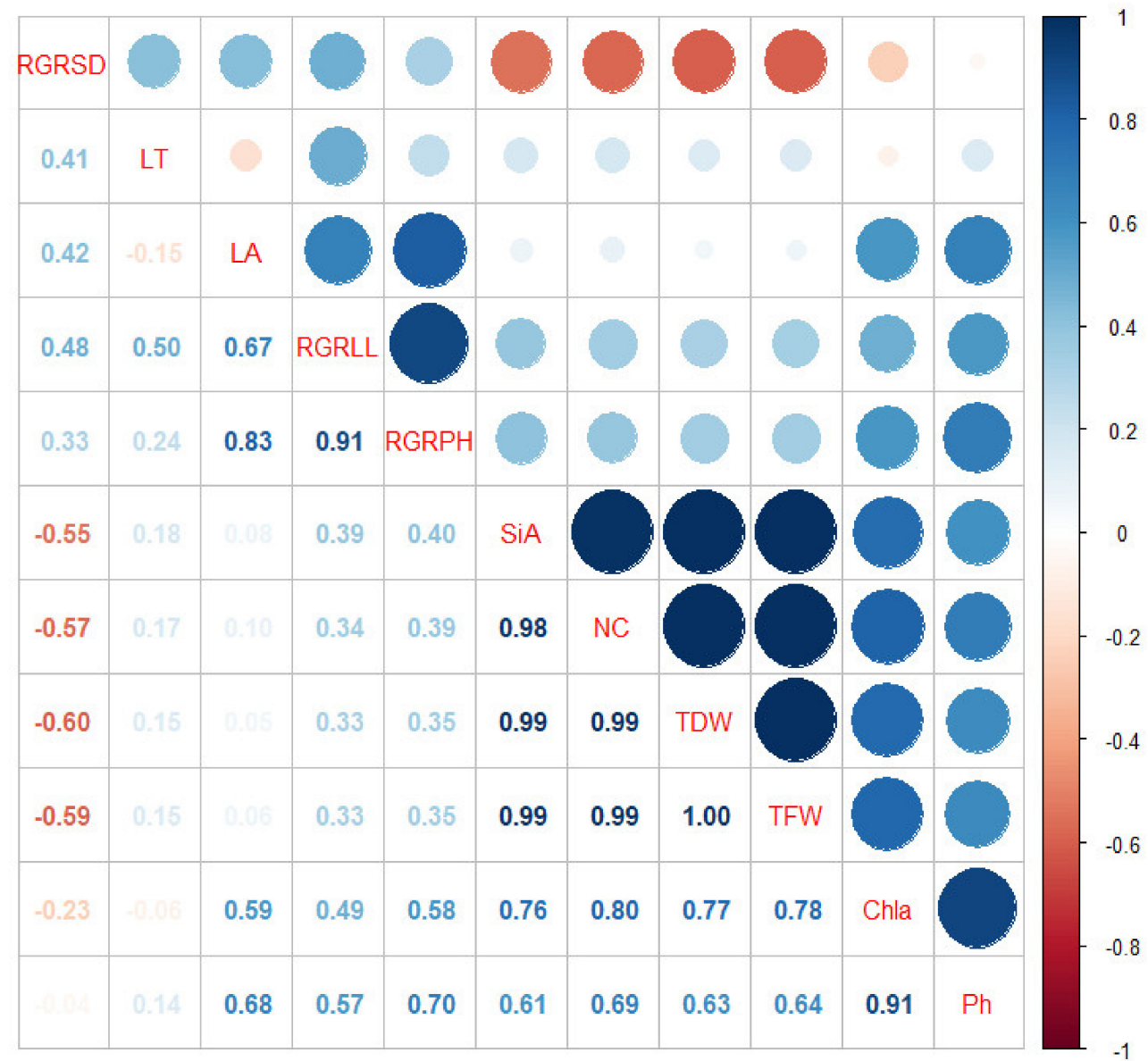

Figure 9. Correlation plot illustrating computed Pearson's correlation coefficients for photosynthesis (Ph), chlorophyll $a$ (Chla), total fresh weight (TFW), total dry weight (TDW), nitrogen content (NC), silicon accumulation $(\mathrm{SiA})$, relative growth rate in terms of plant height (RGRPH), relative growth rate in terms of leaf length (RGRLL), leaf angle (LA), leaf thickness (LT), and relative growth rate in terms of stem diameter (RGRSD). Positive and negative associations are indicated by blue and red circles, respectively. Squares with no colored circles represent a nonsignificant association at $p<0.05$. Computed coefficient values are also listed. The strength of association among different attributes is directly proportional to the color intensity and the size of the circles.

\section{Discussion}

In the oil palm plantation industry, optimum growth and productivity are not achieved due to various factors, among which nutrient management and well-established nursery seedlings are crucial. Uniform and vigorous seedlings are a key component of improved oil palm production $[33,46]$. Therefore, improved nutrient management is necessary to achieve healthy and well-adapted vigorous seedlings [33].

The beneficial effects of $\mathrm{Si}$ on various crops have been studied intensively under various biotic and abiotic stress conditions. However, the effects of $\mathrm{Si}$ on vegetative growth under nonstress conditions have been debated for different plants. Guo et al. [47] reported that alfalfa treated with Si had increased leaf area, height, and forage yield. Costa et al. [48] indicated that $\mathrm{Si}$ fertilization at 0.28 to $0.55 \mathrm{~g} \cdot$ pot $^{-1}$ provided better growth of passion fruit. In addition, $\mathrm{Si}$ application stimulated vegetative growth of rice, sugarcane, strawberry, and soybean $[4,12,49]$. In contrast, applying Si had no significant effect on the growth of Spartina anglica and cowpea [47].

The mechanism via which plants benefit from $\mathrm{Si}$ is still unclear. However, for plants to be affected by $\mathrm{Si}$ fertilization, $\mathrm{Si}$ accumulation needs to be observed [13]. In the present study, oil palm was found to accumulate $\mathrm{Si}$ in all tissues, preferably leaf followed by root 
and stem. According to Tongchu et al. [50], a study on the translocation factor of calcium silicate in oil palm demonstrated that more Si was transferred from the root to the leaf in the presence of calcium silicate compared to the control. Oil palm seedlings accumulated $0.17-0.89 \% \mathrm{Si}$ (dry weight) across the whole plant, which was, therefore, considered to be an intermediate accumulator according to Ma et al. [13]. A positive relationship between $\mathrm{Si}$ accumulation and Si fertilization was noticed in present study. A linear regression relationship between dose of $\mathrm{Si}$ application and the concentration of $\mathrm{Si}$ in leaf tissues of oil palm seedlings was also reported by Putra et al. [51]. Among plants, Si concentration is found to be higher in monocotyledons than in dicotyledons with an increase in the following order: legumes $<$ fruit crops $<$ vegetables $<$ grasses $<$ grain crops [5]. Si is mainly deposited in plant parts as phytoliths $\left(\mathrm{SiO}_{2} \cdot \mathrm{nH}_{2} \mathrm{O}\right)$ [52]. This acts as a physical barrier and, thus, improves plant resistance to pathogens and insects [52]. As foliar deposition of $\mathrm{Si}$ was evidenced in our results, resistance to leaf spot and leaf blight diseases, commonly found in nursery-stage oil palms, should be investigated.

The present study indicated stimulatory effects of Si on fresh weight, dry weight, and relative vegetative growth rate [17]. Similar results were reported in multiple plants $[17,18]$. Biomass production is involved in the coordination of different events including the transition from elongation to thickening of stem tissues and synthesis of secondary cell walls impregnated with lignin, many of which are regulated by phytohormones. It has been proposed that the remaining $\mathrm{Si}$ in the form of soluble silicic acid $\left(\mathrm{Si}(\mathrm{OH})_{4}\right)$ may be involved in stimulating biochemical/molecular processes contributing to biomass production under Si supplementation.

Interactions of $\mathrm{Si}$ fertilization with other plant nutrients including nitrogen have been well documented [53-55]. Si positively affects almost all aspects of nitrogen nutrition, including nitrogen uptake, assimilation, and remobilization, and it has been reported in many crops $[53,56,57]$. Beneficial effects of $\mathrm{Si}$ on plant growth and production have been reported under low, optimal, and excessive nitrogen supply [58]. In oil palm seedlings, nitrogen content was enhanced with the supplementation of Si. The mechanisms underlying the stimulatory effects of Si have not been reported in any plants, but it has been demonstrated that increased nitrogen concentration in plant parts resulted from enhance nitrogen fixation, as well as upregulation of $\mathrm{NO}_{3}{ }^{-}$transporter genes and genes involved in nitrogen uptake.

In the present study, the enhanced growth of oil palm seedlings treated with $\mathrm{Si}$ could be attributed to increased chlorophyll $a$ content and, consequently, photosynthetic rate. Chlorophyll is an important pigment in photon absorption, transmission, and transportation and is closely related to photosynthesis [59]. Nitrogen is required for the production of chlorophyll, nucleic acids, and enzymes. Therefore, increased nitrogen content can improve the chlorophyll content in crop leaves, thus improving photosynthetic performance [60]. A positive correlation among nitrogen content, chlorophyll $a$ content, and photosynthetic rate was also demonstrated in the present study.

Overall, Si fertilization at a certain rate exhibited stimulatory effects on oil palm seedling growth, which could be attributed to increased nitrogen uptake and photosynthesis. An increased growth rate in oil palm seedlings is preferable as it help to shorten the time required for seedling development and establishment. As oil palm plantations are continuously expanded, these beneficial effects of $\mathrm{Si}$ on oil palm can facilitate the production of oil palm seedling to be able to keep up with increased demand for seedling materials. As oil palm was demonstrated to be an intermediate Si accumulator, other beneficial effects of Si fertilization under biotic and abiotic stress conditions can be further investigated to contribute to better nutrient management in oil palm.

\section{Conclusions}

Silicon (Si) fertilization with $3.5 \mathrm{~g}$ and $7.0 \mathrm{~g} \mathrm{Ca}_{2} \mathrm{SiO}_{4} \cdot$ plant $^{-1} \cdot$ month $^{-1}$ stimulated growth and physiological processes of oil palm seedlings under nonstress conditions. Oil palm is an intermediate Si accumulator, and it was observed that a higher proportion of $\mathrm{Si}$ was deposited in the aerial parts, especially the leaf. Chlorophyll $a$ content and photo- 
synthetic rate were positively correlated with Si fertilization and could have contributed to the better growth observed. Nitrogen uptake was demonstrated to be enhanced by Si fertilization. Leaf thickness and leaf angle were not considerably affected by Si fertilization, but slight trends toward more upright leaves with increased Si fertilization were observed and should be further investigated. Overall, Si fertilization provided beneficial effects on growth and physiological responses in oil palm seedlings. Therefore, Si fertilization should be considered for improved nutrient management for healthy and vigorous oil palm seedling and nursery production.

\begin{abstract}
Author Contributions: S.D. conceptualized the study. S.D. and Y.T. conducted the experiments and analyzed data. S.D. and T.H. prepared the first draft. T.E. and J.O. provided technical guidance and edited the manuscript. J.O. proofread the manuscript. All authors contributed to the article and approved the submitted version. All authors have read and agreed to the published version of the manuscript.
\end{abstract}

Funding: This research was funded by Prince of Songkla University, Hat Yai Campus, Thailand through the grant number NAT601300S.

Institutional Review Board Statement: Not applicable.

Informed Consent Statement: Not applicable.

Data Availability Statement: The data presented in this study are available on request from the corresponding author.

Conflicts of Interest: The authors declare no conflict of interest.

\title{
References
}

1. Hodson, M.J.; Evans, D.E. Aluminium/silicon interactions in higher plants. J. Exp. Bot. 1995, 46, 161-171. [CrossRef]

2. Hans Wedepohl, K. The composition of the continental crust. Geochim. Cosmochim. Acta 1995, 59, 1217-1232. [CrossRef]

3. Sommer, M.; Kaczorek, D.; Kuzyakov, Y.; Breuer, J. Silicon pools and fluxes in soils and landscapes-A review. J. Soil Sci. Plant Nutr. 2006, 169, 310-329.

4. Camargo, M.S.; Keeping, M.G. Silicon in sugarcane: Availability in soil, fertilization, and uptake. Silicon 2021, 13, 3691-3701. [CrossRef]

5. Meena, V.D. A case for silicon fertilization to improve crop yields in tropical soils. Proc. Natl. Acad. Sci. India Sect. B Biol. Sci 2014, 84, 505-518. [CrossRef]

6. Dobermann, A.; Fairhurst, T. Rice: Nutrient Disorder \& Nutrient Management; Potash \& Phosphate Institute (PPI), Potash \& Phosphate Institute of Canada (PPIC) and International Rice Research Institute: Laguna, Philippines, $2000 ;$ p. 191.

7. Bari, M.A.; Prity, S.A.; Das, U.; Akther, M.S.; Sajib, S.A.; Reza, M.A.; Kabir, A.H. Silicon induces phytochelatin and ROS scavengers facilitating cadmium detoxification in rice. Plant Biol. 2020, 22, 472-479. [CrossRef]

8. Chaiwong, N.; Rekasem, B.; Pusadee, T. Silicon application improves caryopsis development and yield in rice. J. Sci. Food Agric. 2021, 101, 220-228. [CrossRef]

9. Geng, A.; Wang, X.; Wu, L.; Wang, F.; Wu, Z.; Yang, H.; Chen, Y.; Wen, D.; Liu, X. Silicon improves growth and alleviates oxidative stress in rice seedlings (Oryza sativa L.) by strengthening antioxidant defense and enhancing protein metabolism under arsanilic acid exposure. Ecotoxicol. Environ. Saf. 2018, 15, 266-273.

10. Ahmad, M.; Ahmad, M.; El-Saeid, M.H.; Akram, M.A.; Ahmad, H.R.; Hussain, H.H.A. Silicon fertilization-A tool to boost up drought tolerance in wheat (Triticum aestivum L.) crop for better yield. J. Plant Nutr. 2016, 39, 1283-1291. [CrossRef]

11. Verma, K.K.; Song, X.P.; Zeng, Y.; Guo, D.J.; Singh, M.; Rajput, V.D.; Malviya, M.K.; Wei, K.J.; Sharma, A.; Li, D.P.; et al. Foliar application of silicon boosts growth, photosynthetic leaf gas exchange, antioxidative response and resistance to limited water irrigation in sugarcane (Saccharum officinarum L.). Plant Physiol. Biochem. 2021, 166, 582-592. [CrossRef]

12. Sun, X.; Liu, Q.; Tang, T.; Chen, X.; Luo, X. Silicon fertilizer application promotes phytolith accumulation in rice plants. Front. Plant Sci. 2019, 10, 425. [CrossRef]

13. Ma, J.F.; Miyake, Y.; Takahashi, E. Silicon as a beneficial element for crop plants. In Studies in Plant Science; Datnoff, L.E., Snyder, G.H., Korndörfer, G.H., Eds.; Elsevier: Amsterdam, The Netherlands, 2001; pp. 17-39.

14. Adatia, M.H.; Besford, R. The effects of silicon on cucumber plants grown in recirculating nutrient solution. Ann. Bot. 1986, 58, 343-351. [CrossRef]

15. Hodson, M. Phylogenetic variation in the silicon composition of plants. Ann. Bot. 2005, 96, 1027-1046. [CrossRef]

16. Mitani, N. Uptake system of silicon in different plant species. J. Exp. Bot. 2005, 56, 1255-1261. [CrossRef]

17. Hossain, M.T.; Mori, R.; Soga, K.; Wakabayashi, K.; Kamisaka, S.; Fujii, S.; Yamamoto, R.; Hoson, T. Growth promotion and an increase in cell wall extensibility by silicon in rice and some other Poaceae seedlings. J. Plant Res. 2002, 115, 23-27. [CrossRef] 
18. Ahmed, M.; Qadeer, U.; Hassan, F.; Fahad, S.; Naseem, W.; Duangpan, S.; Ahmad, S. Abiotic Stress Tolerance in Wheat, and the Role of Silicon: An Experimental Evidence. In Agronomic Crops; Hasanuzzaman, M., Ed.; Springer: Singapore, 2020.

19. Ahmad, T.; Haddad, R. Study of silicon effects on antioxidant enzyme activities and osmotic adjustment of wheat under drought stress. Czech J. Genet. Plant Breed. 2011, 47, 17-27. [CrossRef]

20. Berahim, Z.; Omar, H.M.; Zakaria, N.; Ismail, M.R.; Rosle, R.; Roslin, N.A.; Che'ya, N.N. Silicon improves yield performance by enhancement in physiological responses, crop imagery, and leaf and culm sheath morphology in new rice line, PadiU Putra. BioMed Res. Int. 2021, 2021. [CrossRef]

21. Verma, K.K.; Liu, X.H.; Wu, K.C.; Singh, K.R.; Song, Q.; Malviya, M.K.; Song, X.; Singh, P.; Verma, C.L.; Li, Y. The impact of silicon on photosynthetic and biochemical responses of sugarcane under different soil moisture levels. Silicon 2020, 12, $1355-1367$. [CrossRef]

22. Dorairaj, D.; Ismail, M.R.; Sinniah, U.R.; Ban, T.K. Influence of silicon on growth, yield, and lodging resistance of MR219, a lowland rice of Malaysia. J. Plant Nutr. 2017, 40, 1111-1124. [CrossRef]

23. Song, A.; Li, P.; Li, Z.; Liang, Y. The effect of Silicon on photosynthesis and expression of its relevant genes in rice (Oryza sativa L.) under high-zinc stress. PLOS ONE 2014, 9, e113782.

24. Ávila, F.; Baliza, D.; Faquin, V.; Araujo, J.; Ramos, S. Silicon-nitrogen interaction in rice cultivated under nutrient solution. Cienc. Agron. 2010, 41, 184-190. [CrossRef]

25. Reynolds, O.L. Silicon: Potential to promote direct and indirect effects on plant defense against arthropod pests in agriculture Front. Plant Sci. 2016, 7, 744. [CrossRef] [PubMed]

26. Massey, F.P.; Hartley, S.E. Experimental demonstration of the antiherbivore effects of silica in grasses: Impacts on foliage digestibility and vole growth rates. Proc. Biol. Sci. 2006, 273, 2299-2304. [CrossRef] [PubMed]

27. Massey, F.P.; Hartley, S.E. Physical defences wear you down: Progressive and irreversible impacts of silica on insect herbivores. J. Anim. Ecol. 2009, 78, 281-291. [CrossRef]

28. Yang, R.; Howe, J.A.; Golden, B.R. Calcium silicate slag reduces drought stress in rice (Oryza sativa L.). J. Agron. Crop. Sci. 2019, 205, 353-361. [CrossRef]

29. Pei, Z.F.; Ming, D.F.; Liu, D.; Wan, G.L.; Geng, X.X.; Gong, H.J.; Zhou, W.J. Silicon improves the tolerance to water-deficit stress induced by polyethylene glycol in wheat (Triticum aestivum L.) seedlings. J. Plant Growth Regul. 2010, 29, 106-115. [CrossRef]

30. Parveen, A.; Liu, W.; Hussain, S.; Asghar, J.; Perveen, S.; Xiong, Y. Silicon priming regulates morpho-physiological growth and oxidative metabolism in maize under drought stress. Plants 2019, 8, 431. [CrossRef]

31. Torabi, F.; Majd, A.; Enteshari, S. The effect of silicon on alleviation of salt stress in borage (Borago officinalis L.). Soil Sci. Plant Nutr. 2015, 61, 788-798. [CrossRef]

32. Woittiez, L.; Wijk, M.; Slingerland, M.; van Noordwijk, M.; Giller, K. Yield gaps in oil palm: A quantitative review of contributing factors. Eur. J. Agron. 2017, 83, 57-77. [CrossRef]

33. Corley, R.H.V.; Tinker, P.B. The Oil Palm, 4th ed.; Blackwell Publishing: Oxford, UK, 2003; p. 284.

34. Xin, Y.; Sun, L.; Hansen, M.C. Biophysical and socioeconomic drivers of oil palm expansion in Indonesia. Environ. Res. Lett. 2021, 16, 034048. [CrossRef]

35. Pilon-Smits, E.A.; Quinn, C.F.; Tapken, W.; Malagoli, M.; Schiavon, M. Physiological functions of beneficial elements. Curr. Opin. Plant Biol. 2009, 12, 267-274. [CrossRef]

36. Munevar, M.; Romero, F.A. Soil and plant silicon status in oil palm crops in Colombia. Exp. Agric. 2015, 51, 382-392. [CrossRef]

37. Onthong, J.; Osaki, M.; Nilnond, C.; Tadano, T. Phosphorus status of some highly weathered soils in Peninsular Thailand and availability in Relation to citrate and oxamate application. Soil Sci. Plant Nutr. 1999, 45, 627-637. [CrossRef]

38. Bouyoucos, G.J. Directios for making mechanical analyses of soils by the hydrometer method. Soil Sci. 1936, 42, 225-230. [CrossRef]

39. Kjeldahl, J. Neue Methode zur Bestimmung des Stickstoffs in organischen Korpern. Z. Anal. Chem. 1883, 22, 366-382. [CrossRef]

40. Bray, R.H.; Kurtz, L.T. Determination of toal, organic, and available forms of phosphorus in soils. Soil Sci. 1945, 59, 39-46. [CrossRef]

41. Estefan, G.; Sommer, R.; Ryan, J. Methods of Soil, Plant, and Water Analysis: A Manual for the West Asia and North Africa Region; International Center for Agricultural Research in the Dry Areas: Beirut, Lebanon, 2013.

42. Hoffmann, W.; Poorter, H. Avoiding bias in calculations of relative growth rate. Ann. Bot. 2002, 90, 37-42. [CrossRef]

43. Lepeduš, H.; Vidaković-Cifrek, Z.; Šebalj, I.; Dunić, J.A.; Cesar, V. Effects of low and high irradiation levels on growth and PSII efficiency in Lemna minor L. Acta Bot. Croat. 2020, 79, 185-192. [CrossRef]

44. Wei, T.; Simko, V. R Package "Corrplot": Visualization of a Correlation Matrix. Available online: https://github.com/taiyun/ corrplot (accessed on 10 November 2021).

45. Hussain, T.; Hussain, N.; Ahmed, M.; Nualsri, C.; Duangpan, S. Responses of lowland rice genotypes under terminal water stress and identification of drought tolerance to stabilize rice productivity in southern Thailand. Plants 2021, 10, 2565. [CrossRef]

46. Duangpan, S.; Buapet, P.; Sujitto, S.; Eksomtramage, T. Early assessment of drought tolerance in oil palm $D \times P$ progenies using growth and physiological characters in seedling stage. Plant Genet. Resour. C 2018, 16, 544-554. [CrossRef]

47. Guo, Z.G.; Liu, H.X.; Tian, F.P.; Zhang, Z.H.; Wang, S.M. Effect of silicon on the morphology of shoots and roots of alfalfa (Medicago sativa). Anim. Prod. Sci. 2006, 46, 1161-1166. [CrossRef] 
48. Costa, B.N.S.; Dias, G.M.G.; Costa, I.J.S.; Assis, F.A.; Silveira, F.A.S.; Pasqual, M. Effects of silicon on the growth and genetic stability of passion fruit. Acta Sci. 2016, 38, 503-511. [CrossRef]

49. Shamshiripour, M.; Motesharezadeh, B.; Rahmani, H.A.; Alikhani, H.A.; Etesami, H. Optimal concentrations of silicon enhance the growth of soybean (Glycine Max, L.) cultivars by improving nodulation, root system architecture, and soil biological properties. Silicon 2021. [CrossRef]

50. Tongchu, C.; Onthong, J.; Duangpan, S. Effects of calcium silicate fertilizer on silicon accumulation of oil palm seedling. Thai J. Soils Fertil. 2018, 41, 18-25.

51. Putra, E.T.S.; Issukindarsyah, I.; Taryono, T.; Purwanto, B.H.; Indradewa, D. Role of boron and silicon in inducing mechanical resistance of oil palm seedlings to drought stress. J. Appl. Sci. 2016, 16, 242-251. [CrossRef]

52. Luyckx, M.; Hausman, J.F.; Lutts, S.; Guerriero, G. Impact of silicon in plant biomass production: Focus on bast fibres, hypotheses, and perspectives. Plants 2017, 6, 37. [CrossRef]

53. Pavlovic, J.; Kostic, L.; Bosnic, P.; Kirkby, E.A.; Nikolic, M. Interactions of silicon with essential and beneficial elements in plants. Front. Plant Sci. 2021, 12, 697592. [CrossRef]

54. Bokor, B.; Ondoš, S.; Vaculík, M.; Bokorová, S.; Weidinger, M.; Lichtscheidl, I.; Turňa, J.; Lux, A. Expression of genes for Si uptake, accumulation, and correlation of Si with other elements in Ionome of Maize Kernel. Front. Plant Sci. 2017, 8, 1063. [CrossRef]

55. Greger, M.; Landberg, T.; Vaculík, M. Silicon influences soil availability and accumulation of mineral nutrients in various plant species. Plants 2018, 7, 41. [CrossRef]

56. Pati, S.; Pal, B.; Badole, S.; Hazra, G.C.; Mandal, B. Effect of silicon fertilization on growth, yield, and nutrient uptake of rice. Commun. Soil Sci. Plant Anal. 2016, 47, 284-290. [CrossRef]

57. Cuong, T.X.; Ullar, H.; Datta, A.; Hanh, T.C. Effects of silicon-based fertilizer on growth, yield and nutrient uptake of rice in tropical zone of Vietnam. Rice Sci. 2017, 24, 283-290. [CrossRef]

58. Gou, T.; Yang, L.; Hu, W.; Chen, X.; Zhu, Y.; Guo, J.; Gong, H. Silicon improves the growth of cucumber under excess nitrate stress by enhancing nitrogen assimilation and chlorophyll synthesis. Plant Physiol. Biochem. 2020, 152, 53-61. [CrossRef] [PubMed]

59. Liu, Z.; Gao, F.; Yang, J.; Zhen, X.; Li, Y.; Zhao, J.; Li, J.; Qian, B.; Yang, D.; Li, X. Photosynthetic characteristics and uptake and translocation of nitrogen in peanut in a wheat-peanut rotation system under different fertilizer management regimes. Front. Plant Sci. 2019, 10, 86. [CrossRef] [PubMed]

60. Bassi, D.; Menossi, M.; Mattiello, L. Nitrogen supply influences photosynthesis establishment along the sugarcane leaf. Sci. Rep. 2018, 8, 2327. [CrossRef] 